\title{
Uji Aktivitas Analgetika Fraksi-Fraksi Ekstrak Etanol Daun Gandarusa (Justicia gendarussaBurm. f) dengan Metode Tail Flick
}

\section{Analgetic Activity Assay of Etanolic Extract Fractions of Gandarusa (Justicia gendarussa Burm. f) Leaves using Tail Flick Method}

\author{
Rosa Juwita Hesturini ${ }^{1)}$, Rina Herowati ${ }^{2}$ dan Gunawan Pamudji Widodo ${ }^{2)}$ \\ 1) Fakultas Farmasi,Institut Ilmu Kesehatan Kediri, Jawa Timur. \\ 2) Fakultas Farmasi, Universitas Setia Budi Surakarta, Jawa Tengah.
}

\begin{abstract}
ABSTRAK
Gandarusa (Justicia gendarussa Burm. $\mathrm{f}$ ) adalah tanaman potensial sebagai analgetik dengan kandungan senyawa steroid, terpenoid dan alkaloid. Tujuan dari penelitian ini adalah mengetahui aktivitas analgetik ekstrak etanol dan fraksi-fraksi gandarusa dengan metode tail flick pada hewan uji tikus putih.

Ekstrak etanol difraksinasi dengan pelarut $n$-heksana, etil asetat dan air. Uji analgetik dilakukan dengan metode tail flick yaitu dengan pemberian panas terukur pada ekor dan dilakukan pengukuran waktu penarikan ekor hewan uji. Dosis ekstrak dan fraksi daun gandarusa berturut-turut yaitu $250 \mathrm{mg} / \mathrm{kgbb}, 500 \mathrm{mg} / \mathrm{kgbb}$, fraksi n-heksana $314 \mathrm{mg} / \mathrm{kgbb}$, fraksi $41,05 \mathrm{mg} / \mathrm{kgbb}$ dan fraksi air $144,8 \mathrm{mg} / \mathrm{kgbb}$, kelompok kontrol negatif CMC $0.5 \%$ dan asetosal $360 \mathrm{mg} / \mathrm{kgbb}$. Hasil penelitian menunjukkan aktivitas analgetik optimal pada fraksi $n$-heksana dengan persentase antinociceptif sebesar $94,58 \%$ dan sebanding dengan kelompok kontrol positif asetosal.
\end{abstract}

Kata kunci : Gandarusa, analgetik, anti-inflamasi, karagenan, tail flick

\section{ABSTRACT}

Gandarusa (Justicia gendarussa Burm. $\mathrm{f}$ ) is a potential plant as analgetic activities. The aim of the present research was to investigate the analgetic activity with tail flick method on rat models of ethanol extract and the fractions of gandarusa leaf.

Partitioned fractinations isolated from ethanolic extract of gandarusaleaves with $\mathrm{n}$ heksana, etil asetat and water. Dosage extracts and fractions gandarusa leaf, respectively, are $250 \mathrm{mg} / \mathrm{kg} \mathrm{bw}, 500 \mathrm{mg} / \mathrm{kg} \mathrm{bw}, \mathrm{n}$-hexane fraction of $314 \mathrm{mg} / \mathrm{kg} \mathrm{bw}$, the fraction of $41,05 \mathrm{mg} / \mathrm{kg}$ bw and water fractions $144,8 \mathrm{mg} / \mathrm{kg}$ bw, the negative control group CMC and aspirin $360 \mathrm{mg} / \mathrm{kg}$ bw. The results showed the $n$-heksana fraction has optimal analgesic activity with antinociceptive percentage $94,58 \%$ comparable to aspirin.

The preliminary phytochemical analisys showed the presence of active phytochemical such as flavonoids, alkaloids, saponins, steroids dan tannins and these compound might be responsible for analgetic mechanism. The possibility analgetic mechanism of the gandarussa its stimulate lipomodulin protein biosynthesis which inhibit the action of phospolipase enzimatic that affecting the enzyme activity arachidonic acid but there is also has gastroprotective activity with increased mucus production and prevents the release of histamine.

Keywords : Gandarusa, analgetic, anti-inflammatory, carragenan, tail flick

\section{PENDAHULUAN}

Nyeri adalah ciri terjadinya inflamasi, yang merupakan sensasi rasa sakit kurang lebih terlokalisir akibat rangsangan pada ujung saraf khusus. Nyeri berfungsi sebagai 
mekanisme pelindung karena membuat kita menarik diri atau menjauhi sumbernya (Anonim, 1996). Nyeri dapat disebabkan oleh rangsangan atau trauma mekanik, fisika, kimia maupun trauma lain yang yang mengakibatkan rangsangan pada reseptor nyeri. NSAIDs (Non-Steroid Anti-Inflammation Drugs) sebagai analgetik mempunyai kemampuan untuk menghambat siklooksigenase (COX) dan inhibisi sintesis prostaglandin (Neal, 2006). Namun inhibisi sintesis prostaglandin yang juga berfungsi sebagai proteksi mukosa lambung, menstimulasi mukus dan sekresi bikarbonat dan menyebabkan vasodilatasi menjadi terganggu. Pada penggunaan salisilat, efek yang paling sering terjadi adalah distres epigastrik, disertai mual, muntah dan perdarahan (Harvey, 2014; Tjay \& Raharja, 2007; Neal, 2006).

Salah satu tanaman Indonesia yang secara empiris digunakan untuk terapi analgetik adalah tanaman gandarusa. Batang dan daun gandarusa diketahui mengandung fenol, flavonoid, tanin, alkaloid, steroid (Chandrashekar, 2013), glikosida dan saponin (Chinna, 2010). Tanaman ini diketahui mengandung stigmasterol, lupeol dan 16-hidroksilupeol yang diisolasi dari fraksi pretroleum eter dari keseluruhan tanaman gandarusa (Uddin, 2011), triterpenoid, justicin, dan gendarusin A senyawa mayor flavonoid dan gendarusin B senyawa minor flavonoid (Prajogo, 2007). Hasil penelitian pada ekstrak etanol daun gandarusa menunjukkan adanya aktivitas sebagai anti-nociceptif dengan peningkatan waktu latensi menggunakan metode hot plate dan sebagai anti-inflamasi dengan adanya penurunan terhadap volume udema (Shikha, 2010)

Tujuan dari penelitian ini adalah untuk mengetahui aktivitas analgetik dengan metode tailflick dan dosis paling efektif pada ekstrak etanol, fraksi $n$-heksana, fraksi etil asetat dan fraksi air daun gandarusa.

\section{METODE PENELITIAN}

\section{Bahan}

Daun gandarusa (Justicia gendarussa Burm. f), asetosal (Phapros Factory), etanol 96\%, n-heksana, etil asetat, aquades,plat silika GF254, anisaldehid asam sulfat, asam sitroborat, $\quad \mathrm{FeCl}_{3}, \quad$ Dragendorf, Lieberman-Burchard, asam formiat.

\section{Alat}

Seperangkat alat maserasi dan fraksinasi, evaporator, waterbath, moisture balance, alat suntik peroral (Becton Dickinson), radiant heat automatic tail flick analgesiometer LE7106 versi V29/10/2014X, camera digital (Cannon).

\section{Hewan uji}

Tikus albino galur Wistar berumur 3-4 bulan, jenis kelamin jantan dengan berat180-210 gram. Sebelum dilakukan percobaan, hewan terlebih dahulu diadaptasikan selama satu minggu dengan pakan pellet dalam kandang di laboratorium farmakologi dan toksikologi Universitas Setia Budi Surakarta, Jawa Tengah.

\section{Uji aktivitas analgetik}

Tikus dikelompokkan menjadi 7 kelompok : K1 (kontrol negatif), K2 (kontrol positif), K3 (ekstrak 250 
$\mathrm{mg} / \mathrm{kgbb}$ ), K4 (ekstrak $500 \mathrm{mg} / \mathrm{kgbb}$ ), K5 (fraksi n-heksana $314 \mathrm{mg} / \mathrm{kgbb}$ ), K6 (fraksi etil asetat $41,05 \mathrm{mg} / \mathrm{kgbb}$ ), $\mathrm{K} 7$ (fraksi air 144,85 mg/kgbb), beri perlakuan dosis, kemudian setelah 15 menit ekor tikus (1-2 cm dari ujung) diletakkan di bawah phototransistor, disinari dengan inframerah fokus 40. Waktu yang dicatat adalah respon tikus menarik atau mengibaskan ekor sebagai waktu latensi. Respon nociceptif diukur setiap interval 15 menit selama 60 menit (Kakoti, 2013) dan dihitung dengan rumus (Nurrochmad, 2004) : \%Antinociceptif = ( $\mathrm{T}$ latensi $-\mathrm{T}_{0}$ latensi)/ (waktu cut off $\mathrm{T}_{0}$ latensi) $\mathrm{X} 100$

\section{HASIL DAN PEMBAHASAN Hasil uji analgetik (uji tail flick)}

Hasil pengamatan rata-rata persentase antinociceptif dilakukan hingga menit ke-60 dan dijelaskan pada gambar kurva 1. Pada kurva dapat dilihat rata-rata \% antinociceptif kelompok asetosal yaitu 93,69\%, sedangkan ekstrak etanol daun gandarusa $250 \mathrm{mg} / \mathrm{kg}$ bb sebesar $37,36 \%$. Diduga hal ini terjadi karena dosis yang digunakan merupakan dosis yang rendah. Rata-rata \% antinociceptif kelompok fraksi n-heksana sebesar $94,58 \%$ dan memiliki aktivitas yang hampir sama kuat dengan kelompok asetosal. Hal ini dapat dipengaruhi oleh besarnya rendemen fraksi n-heksana sebesar $60,71 \%$. Kandungan senyawa yang dapat larut dalam pelarut $\mathrm{n}$ heksana yaitu terpenoid, triterpenoid, steroid dan fenil propanol (Tiwari, 2011).
Hasil identifikasi pada fraksi n-heksana daun gandarusa mengandung steroid dan terpenoid yang dapat merangsang biosintesis protein lipomodulin yang dapat menghambat kerja enzimatik fosfolipase, yaitu enzim yang bertanggung jawab terhadap pelepasan asam arakhidonat dan memblok jalur siklooksigenase dan lipooksigenase sehingga metabolitnya yaitu prostaglandin, leukotrien, prostasiklin dan tromboksan juga tidak dapat terbentuk. Sama halnya dengan flavonoid yang juga mempengaruhi pengaturan aktivitas metabolisme enzim asam arakhidonat (Chinna, 2010), sedangkan adanya kandungan saponin yang dapat dikelompokkan berdasarkan aglikonnya yaitu saponin triterpenoid dan saponin steroid juga memiliki aktivitas analgetik, anti-inflamasi dan sitotoksik (Gotama, 1999). Tannin memiliki aktivitas analgetik dengan menghambat cyclooksigenase-1 (Pan, 2010). Maka banyaknya rendemen fraksi n-heksana dan berbagai kandungan senyawa yang dimiliki memungkinkan semakin banyak pula kandungan senyawa yang terabsorbsi sehingga penghambatan fosfolipase dalam pembentukan prostaglandin maupun leukotrien juga tidak terbentuk dan aktivitas analgetik yang dihasilkan semakin besar, sedangkan pada kelompok ekstrak etanol $250 \mathrm{mg} / \mathrm{kg}$ bb sebesar 37,36\% dan pada kelompok ekstrak $500 \mathrm{mg} / \mathrm{kg}$ bb sebesar $50,75 \%$. 


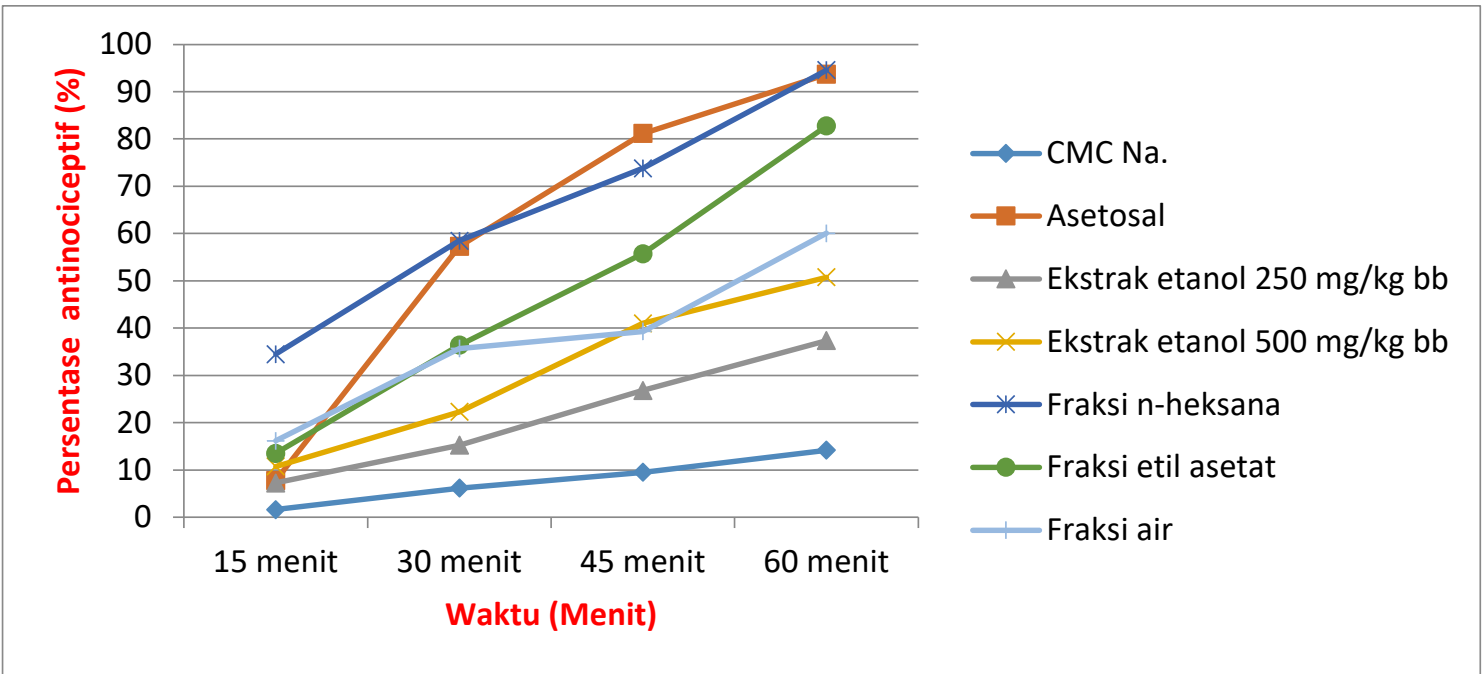

\section{Gambar 1. Kurva data rata-rata persentase antinociceptif}

Pada fraksi etil asetat rata-rata \% antinociceptif sebesar 82,73\%. Kandungan senyawa yang dapat larut dalam pelarut etil asetat yaitu flavonoid aglikon (Tiwari, 2011). Hasil identifikasi pada fraksi etil asetat daun gandarusa mengandung flavonoid, alkaloid, saponin, tanin dan steroid. Adanya kandungan senyawa flavonoid yang mudah larut pada pelarut etil asetat diduga berperan penting dalam aktivitas penghambatan nyeri pada fraksi etil asetat ini dimana flavonoid dapat menghambat jalur 5-lipooksigenase dan jalur COX-2 yang memproduksi mediator nyeri, hal ini sesuai dengan penelitian Paval (2009) bahwa pada tanaman gandarusa mengandung sitosterol, alkaloid, flavonoid vitekin dan apigenin yang memiliki aktivitas sebagai analgetik dan anti-inflamasi.

Pada fraksi air dengan \% antinociceptif sebesar $60,04 \%$ memiliki kandungan senyawa saponin yang dapat memberikan aktivitas analgetik karena saponin dikelompokkan berdasarkan aglikonnya yaitu saponin triterpenoid dan saponin steroid juga memiliki aktivitas analgetik, anti-inflamasi dan sitotoksik (Gotama, 1999).

Hasil pengamatan yang dilakukan dengan metode tail flick ini menunjukkan bahwa adanya perbedaan onset pada masing-masing kelompok perlakuan serta tidak semua pemberian perlakuan menghasilkan rata-rata puncak waktu respon yang sama, hal ini dipengaruhi faktor metabolisme obat atau ekstrak yang diberikan kepada hewan uji. Ekstrak dan fraksi yang menggunakan pelarut non-polar seperti n-heksana menarik senyawa non-polar yang mudah larut lemak atau lipofilik dan akan lebih mudah menembus membran sel pada fase absorbsi dibanding senyawa polar sehingga senyawa non-polar akan memberikan onset yang lebih cepat.

\section{KESIMPULAN}

Fraksi $n$-heksana memiliki aktivitas analgetik \% antinociceptif sebesar $94,58 \%$, aktivitas ini sebanding dengan kontrol positif asetosal. 
UCAPAN TERIMA KASIH

Penulis berterima kasih kepada laboratorium Farmakologi Toksikologi Fakultas Farmasi Universitas Setia Budi Surakarta.

\section{DAFTAR PUSTAKA}

Chandrashekar K. R., Bhagya N. 2013. In Vitro Production Of Bioactive Compounds From Stem and Leaf Explants Of Justicia gendarussa Burm. F. Asian Journal Of Pharmaceutical And Clinical Research . Vol 6, Issue 1. 100105.

Chinna Manickam, Devi P. R., Fazaludeen M. F. 2010. Evaluation of Anti-Inflammatory Activity of Justicia gendarussa Burm.f. Leaf Extract in Adjuvan Induced Arthritis Rats. Int $\mathrm{J}$ Med Res. 163-169.

Gusdinar T., Herowati R., Kartasasita R.E., Adnyana I. K. 2009. Sintesis Kuersetin Terklorinasi dan Aktivitas Perlindungan Terhadap Tukak Lambung. Majalah Farmasi indonesia. 20(4). 163-169.

Junquiera L. C., Carneiro J. 2007. Basic Histology Text and Atlas. Ed ke-11. Department of Celland Developmental Biology Institute of Biomedical Sciences University of SÃ£o Paulo. Brazil. 1-42.

Kakoti B. B., Pradhan P., Borah S., Mahato K., Kumar M. 2013. Analgesic and Anti-Inflammatory
Activities of the Methanolic Stem Bark Extract of Nyctanthes arbortristis Linn. Hindawi Publishing Corporation. BioMed Research International. Vol 2013, Article ID 826295. 1-6.

Kumar J., Nino, Lourthuraj A. 2012. In vitro Regeneration and Phytochemical Analysis of Justicia gendarussa. Indian Journal Innovation Dev., Vol. 1, No. 2. 106-110.

Nurrochmad A., Masahiko O., Narita M., Suzuki T. 2004. The Advantages of Fentanyl For The Treatment of Pain: Studies of Pharmacological Profiles and Fentanyl Related Side Effects. Majalah Farmasi Indonesia. 15(4). 185-193.

Paval J., et al. 2009. Anti-arthritic Potential of the Plant Justicia gendarussa Burm F.Clinical Science; 64(4). 357-60.

Prajogo B. E., Guliet D., Queiroz E. F., Wolfender John-Luc., Cholies N., Hostettmann K. 2009. Isolation of male anti-fertility Compound In NButanol Fraction Of Justicia Gendarussa Burm. f. Leave. Folia Medica Indonesiana. Vol. 45. No. 1 January- March: 28-31.

Uddin Rakib Md. R., Sinha S., et al. 2011. Chemical and Biological Investigations of Justicia gendarussa (Burm. f). Dhaka Univ. J. Pharm. Sci. 10(1); 53-57. 